\title{
TRANSPORT OF PHENOL THROUGH INCLUSION POLYMER MEMBRANE (PIM) USING COPOLY(EUGENOL-DVB) AS MEMBRANE CARRIERS
}

\author{
Agung Abadi Kiswandono ${ }^{1,2, *}$, Dwi Siswanta ${ }^{2}$, Nurul Hidayat Aprilita ${ }^{2}$, and Sri Juari Santosa ${ }^{2}$ \\ ${ }^{1}$ Faculty of Public Health, Prima University, Medan, Indonesia \\ ${ }^{2}$ Department of Chemistry, Faculty of Mathematics and Natural Sciences, Universitas Gadjah Mada, \\ Sekip Utara, Yogyakarta, Indonesia, 55281
}

Received November 7, 2011; Accepted January 23, 2012

\begin{abstract}
Copoly(eugenol-DVB) with DVB composition of $2 \%, 6 \%$ and $12 \%$ had been prepared and characterized by FTIR spectroscopy. The copolymers were used as membrane carriers for the transport of phenol using the polymer inclusion membranes (PIM) based on polyvinylchloride (PVC) as membrane support. The experimental conditions for investigation of the transport of phenol through the membranes including $\mathrm{pH}$ of the source phase, $\mathrm{NaOH}$ concentration in the stripping phase, membrane thickness, membrane carrier concentration and transport time were optimized. The results showed that the optimum condition for phenol transport was achieved on the membrane based on copoly(eugenol-DVB) $12 \%$ with the transport efficiency of $75.6 \%$ at $\mathrm{pH}$ of the source phase of $4.5, \mathrm{NaOH}$ concentration of $0.25 \mathrm{M}$ and transport time of $48 \mathrm{~h}$. The reaction follows first order kinetics with mass transfer coefficient $(k)$ of 2.72 and permeability $\left(P_{s}\right)$ of $1.5 \times 10^{-4} \mathrm{~m} / \mathrm{s}$.
\end{abstract}

Keywords: crosslinked polymer; polymer inclusion membranes; membrane carrier; divinylbenzene

\section{ABSTRAK}

Telah dibuat kopoli(eugenol-DVB) dengan variasi berat divinil benzena (DVB) terhadap eugenol berturut-turut $2 \%, 6 \%$ dan $12 \%$ (b/b) kemudian polimer hasil sintesis dikarakterisasi menggunakan spektroskopi inframerah. Polimer hasil sintesis tersebut digunakan sebagai membran pembawa (carrier) untuk transpor fenol menggunakan metode Polymer Inclusion Membranes (PIM) berbasis polivinilklorida (PVC) sebagai membran pendukung. Beberapa kondisi penelitian telah dioptimasi yang meliputi $\mathrm{pH}$ pada fasa sumber, konsentrasi $\mathrm{NaOH}$ pada fasa pelucut, ketebalan membran, konsentrasi membran pembawa dan waktu transpor. Hasil penelitian menunjukkan, bahwa kondisi transpor optimum fenol tercapai pada kopoli(eugenol-DVB) 12\% dengan persen transpor sebesar 75,6\%. Kondisi optimum ini tercapai pada $\mathrm{pH}$ fenol 4,5, konsentrasi $\mathrm{NaOH}$ 0,25 M dan waktu transpor 48 jam. Reaksi mengikuti kinetika orde satu dengan koefisien transfer massa ( $k$ ) sebesar 2,72 dan permiabilitas (Ps) sebesar $1.5 \times 10^{-4} \mathrm{~m} / \mathrm{s}$.

Kata kunci : sambung silang; polymer inclusion membranes; membran pembawa; divinilbenzena (DVB)

\section{INTRODUCTION}

The worldwide production and use of phenol and its derivatives have increased significantly. Consequently, phenol and its derivatives were commonly found as chemical pollutants in the industrial wastewater. Phenols are produced from the factory processes, such as resins, dyes, pharmaceuticals, paints, antiseptic, and wood products. The use of phenol is considerably high, allow the waste containing phenols will be delivered and pollute the water environment, and most of these compounds are biologically nondegradable pollutant. Phenol concentration in the wastes varies in wide range from several $\mathrm{ppm}$ to $2-3 \%$ [1].
Therefore, the major concern is to treat the phenol in the waste water before it is discharged into the environment.

There are many methods available for the removal of phenols from industrial waste water, but the liquid membrane (LM) processes could be regarded as a successful method, cheap and needless large energy for the treatment of waste water containing organic compounds and metals in comparison with solvent extraction for recovery [2-3]. LM processes combine extraction and stripping into one single stage and thus non-equilibrium mass transfer characteristic where the separation is not limited by the equilibrium conditions [4]. The various configurations of LM include emulsion liquid membrane (ELM), bulk liquid membrane (BLM),

* Corresponding author

Email address : nau_shila@yahoo.com

Agung Abadi Kiswandono et al. 
contained liquid membrane (CLM), supported liquid membrane (SLM), electrostatic pseudo liquid membrane (ESPLIM) and polymer inclusion membrane (PIM) [2,5].

There are many reports on PIM as a modification of the SLM, due to the instability of the SLM for the compound carrier leakage [4,6-9]. PIM is made from a solution containing a carrier compound, plasticizer and polyvinyl chloride (PVC) as a matrix polymer that forms a thin, stable and flexible film. The existence of the matrix polymer membrane is expected to overcome the carrier leakage and the presence of plasticizer can stabilize the membrane system [5,10-12]. Transport process of target compounds from source phase to stripping phase in PIM can be explained in three consecutive steps. In the first, the target solute after diffusing through the aqueous stagnant layer at the source solution/membrane interface reacts with the carrier to form a complex, which is then transported across this interface. In the second, the complexes diffuse across the membrane toward the receiving solution. Finally, at the membrane/receiving solution interface, the complex dissociates and the target solute is released into the receiving solution, which is essentially the reverse of the process occurring at the source solution/membrane interface [5]

PIM is usually evaluated using flux stability parameter [5]. Kim et al. [13] and Levitskaia [14] using the calyx[6]arene and calyx[4]arene as carrier membrane to study the flux and lifetime. A variety of polymer membranes as the carrier has also been used in several studies with various methods of liquid membrane [15-17]. In this study, copoly(eugenol-DVB) were employed as a membrane carrier for the transport of phenol. Copoly(eugenol-DVB) which has many phenolic hydroxyl group was expected to have ability to interact with the phenol, so that it could extract the phenol in the source phase into the membrane phase. Copolymerization with DVB was carried out in order to stabilize the membrane and to reduce the loss of the membrane carrier. The effect of the $\mathrm{pH}$ at source phase, $\mathrm{NaOH}$ concentration, thickness and concentration of membrane, time of the transport, flux and permeability have been systematically studied in this research.

\section{EXPERIMENTAL SECTION}

\section{Materials}

All reagents were analytical grade and were used without further purification. Eugenol was supplied by PT Indesso Aroma, Purwokerto, Indonesia. Poly(vinyl chloride) (PVC), tetrahydrofuran (THF), divinylbenzene (DVB), boron three fluoride diethyl ether, $\mathrm{BF}_{3} \mathrm{O}\left(\mathrm{C}_{2} \mathrm{H}_{5}\right)_{2}$ dibenzyl ether (DBE), $\mathrm{NaOH}, 4$-aminoantipyrine, are products of Merck. All the organic chemicals were used as received. The $\mathrm{pH}$ of the source and of the receiving

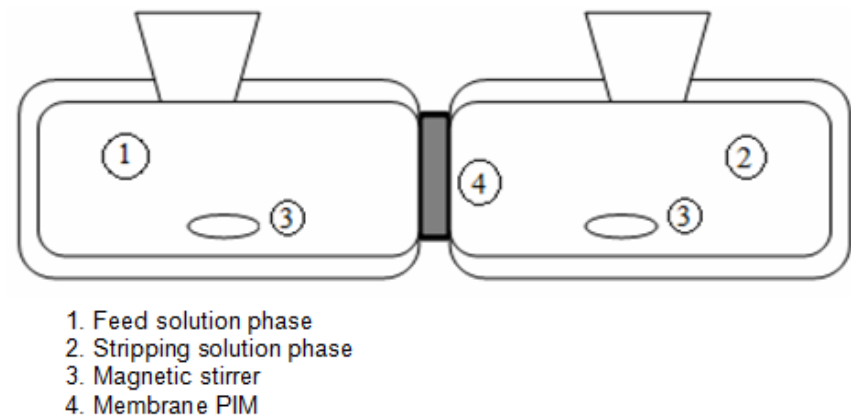

Fig 1. Experimental set-up

Table 1. Composition of compound for membrane PIM

\begin{tabular}{cccc}
\hline No & DVB-Eugenol $(\mathrm{g})$ & PVC $(\mathrm{g})$ & DBE $(\mathrm{g})$ \\
\hline 1 & 0.027 & 0.0864 & 0.1566 \\
2 & 0.054 & 0.1728 & 0.3132 \\
3 & 0.108 & 0.3456 & 0.6264 \\
\hline
\end{tabular}

phase was adjusted using $\mathrm{HCl}$ (Merck) and $\mathrm{NH}_{4} \mathrm{OH}$ (Merck).

\section{Instrumentation}

Infrared spectrometer (FTIR, Shimadzu Prestige21), pH meter (HANNA Instruments, M-18654), UV-spectrometer (772-Spectrophotometer), Scanning Electron Microscope (SEM, JSM-6360 LA) were used for measurements. The PIM cell consists of a cylindrical chamber that is separated into two halves by membrane PIM (Fig. 1).

\section{Procedure}

\section{Synthesis of copoly(eugenol-DVB)}

Three copolymers were obtained by mixing eugenol (5.8 g) and DVB at various weights of $2 \%, 6 \%$, and $12 \%$ (relative to weight of eugenol) in the flask. Then $1 \mathrm{~mL} \mathrm{BF}_{3} \mathrm{O}\left(\mathrm{C}_{2} \mathrm{H}_{5}\right)_{2}$ was added as catalysts. Polymerization reaction was carried overnight and terminated by adding $1 \mathrm{~mL}$ of methanol. Red gel was obtained and dissolved in diethyl ether and then washed with deionized water until neutral $\mathrm{pH}$. The anhydrous $\mathrm{Na}_{2} \mathrm{SO}_{4}$ was added into the organic layer. The solvent was evaporated and the residue was dried in a desiccators. Polymers formed were weighed and the yields were calculated. The products were characterized by infrared spectrometer (FTIR, Shimadzu Prestige-21). For all samples, the same weight of was used for FTIR measurement $(2.5 \mathrm{mg})$.

\section{Preparation of PIM}

PIM were prepared by mixing copoly(eugenolDVB) as membrane carrier, PVC as matrix polymer and DBE as plasticizer as shown in Table 1. THF was added 


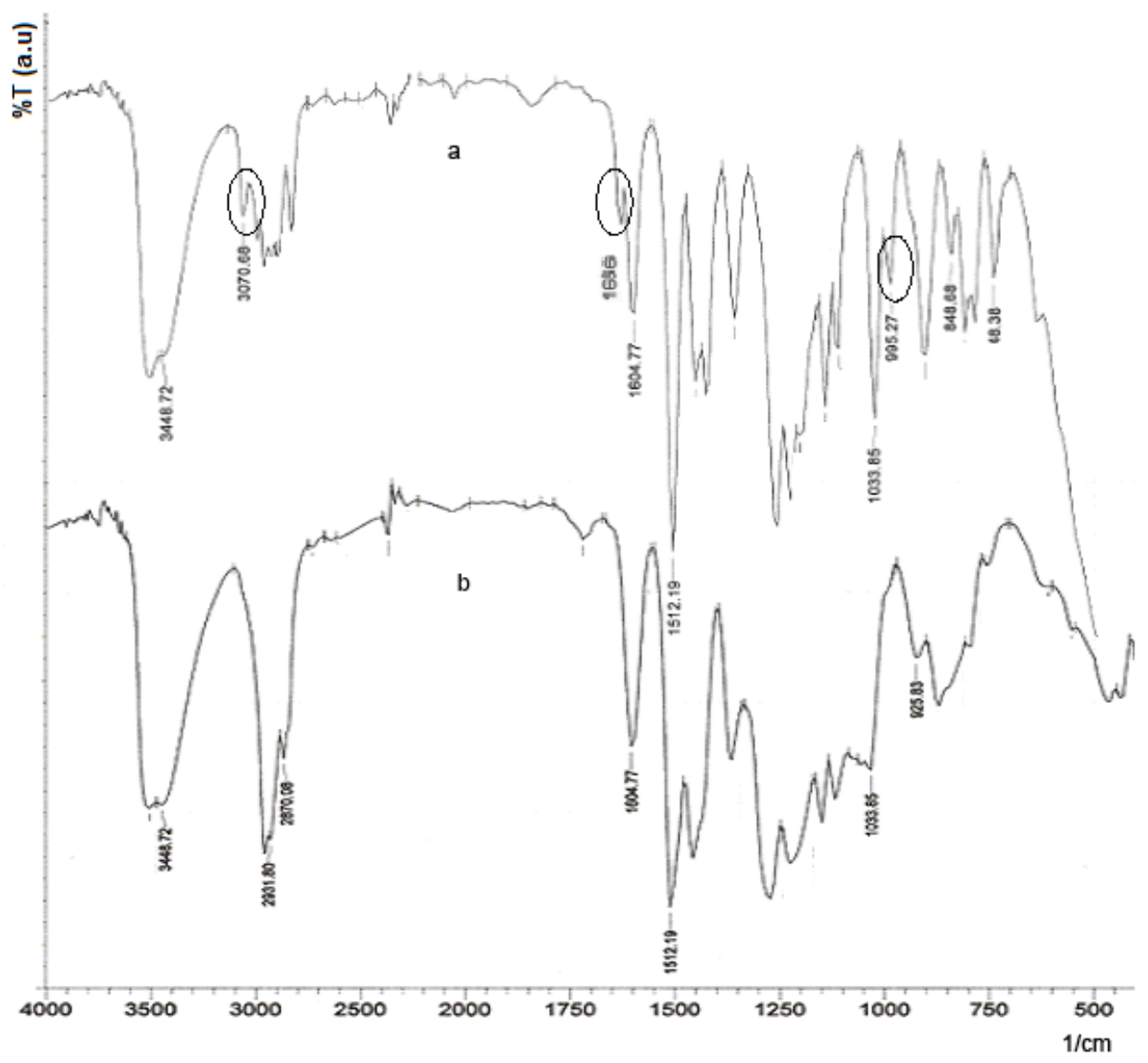

Fig 2. Spectra of IR (a) eugenol, (b) copoly(eugenol-DVB) 2\%

Table 2. Yield and melting point of copoly(eugenol-DVB)

\begin{tabular}{ccc}
\hline DVB $(w / w)^{*}$ & Yield $(\%)$ & Melting point $\left({ }^{\circ} \mathrm{C}\right)$ \\
\hline $2 \%$ & 74.16 & $88.4-95.7$ \\
$6 \%$ & 71.21 & $89.0-102$ \\
$12 \%$ & 67.42 & $100.6-109$ \\
\hline
\end{tabular}

$\left.{ }^{*}\right) \%$ of weight DVB to Eugenol

to homogenize the mixtures using magnetic stirrers, and then leave for 3 days to evaporate the solvent slowly.

\section{Transport of phenol using polymer synthesis}

The aqueous feed solution was prepared by dissolving phenol in deionized water at various concentrations. $\mathrm{NaOH}$ solution was used as the stripping phase. Transport process was done by placing $50 \mathrm{~mL}$ of phenol solution ( $60 \mathrm{ppm})$ into the source phase chamber and $50 \mathrm{~mL}$ of $\mathrm{NaOH}$ into the stripping phase chamber, and stirred at room temperature. The concentration of phenol present in the source and stripping phases were analyzed using 4-aminoantipyrine method [18-19] and the absorbance was measured using UV-visible spectrometer (772-spectrophotometer) at wavelength of $450 \mathrm{~nm}$. Transport parameters evaluated were the $\mathrm{pH}$ at source phase, $\mathrm{NaOH}$ concentration at stripping phase, concentration of the membrane carrier, transport time, and the mole ratio of the membrane carrier. The membrane before and after used in the transport experiments were characterized by Scanning Electron Microscope (SEM, JSM-6360 LA) to evaluate its morphological change during the transport experiment.

\section{Determination of transport flux}

The PIM cell consisted of two halves of a cylindrical chamber separated by the membrane, one chamber was filled phenol feed solution, and the other with $\mathrm{NaOH}$ stripping solution. The aqueous solution in each chamber were stirred using magnetic stirrer. The effective volume of each chamber was $50 \mathrm{~mL}$ and the effective contact of the aqueous solutions, (the effective part) was $25 \mathrm{~mm}$ in diameter. After the transport process, $5 \mathrm{~mL}$ of phenol feed solution was taken and the concentration of phenol was determined by the 4-aminoantipyrine method. Flux (Js) of phenol was calculated by using the following equation:

$\mathrm{J}_{\mathrm{s}}=\mathrm{P}_{\mathrm{s}} \mathrm{C}_{\mathrm{s}}$

where $\mathrm{C}_{\mathrm{s}}$ is the concentration of phenol at time $t$ and $\mathrm{P}_{\mathrm{s}}$ is the permeability coefficient (calculated from kinetic data). 


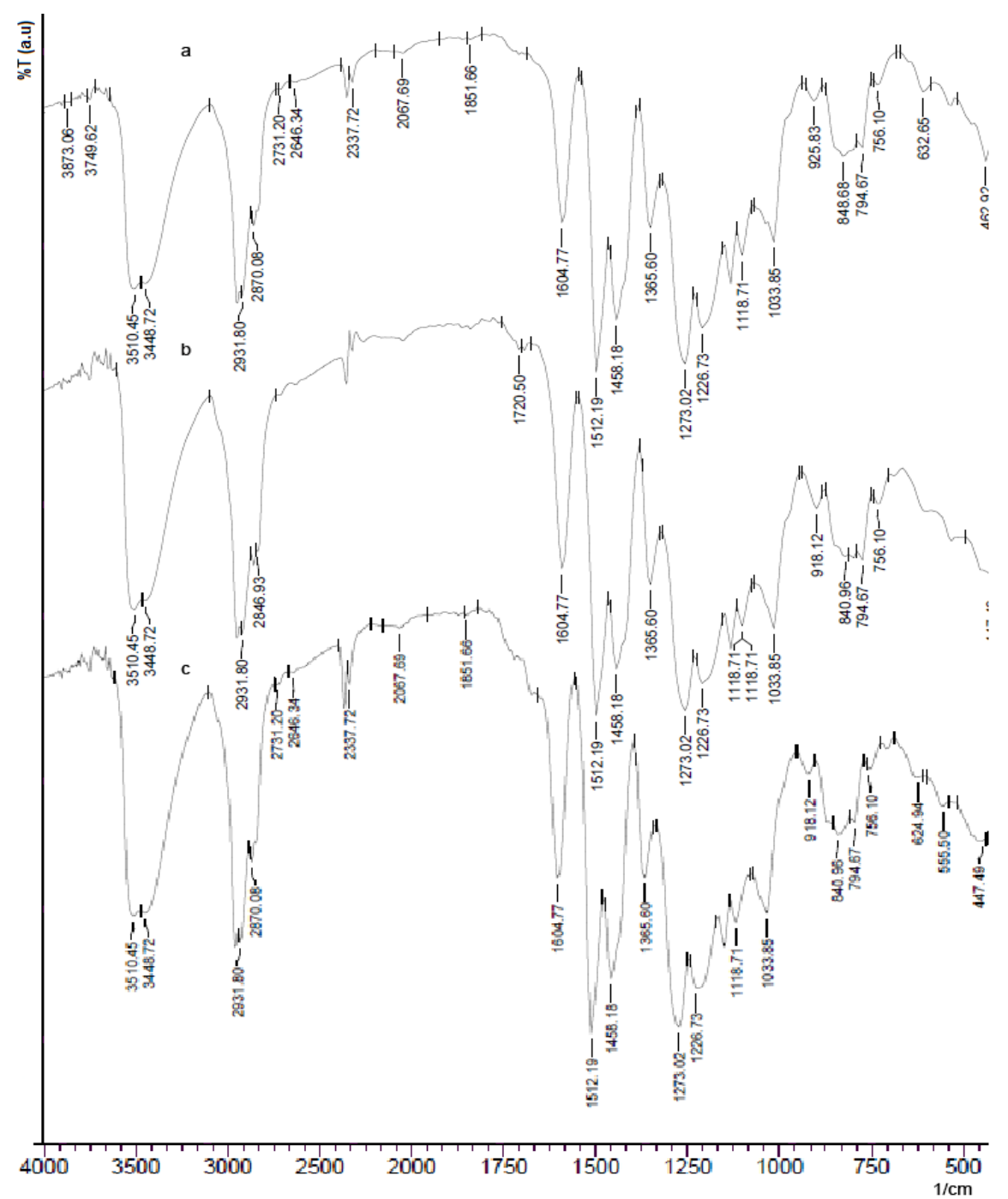

Fig 3. Spectra of IR copoly(eugenol-DVB) (a) $2 \%$, (b) $6 \%$ and (c) $12 \%$

\section{RESULT AND DISCUSSION}

\section{Synthesis of copoly(eugenol-DVB)}

In this study, three copoly(eugenol-DVB) have been successfully synthesized using $\mathrm{BF}_{3}$ as a catalyst through a cationic polymerization. It is observed that process increasing the amount of DVB in the copolymer will increase the melting point of the resulted copoly(eugenol-DVB) as shown at Table 2. The increase in melting point is in linear correlation to the number of DVB added. Addition of more DVB in the copolymer may increase both the rigidity of the polymer and the molecular weight of the polymer, and therefore the melting point of the polymer will rise as of the degree of crosslinked polymer.

Fig. 2a-b presents the FTIR spectra of eugenol and copoly(eugenol-DVB) 2\%. For the eugenol (Fig. 2a), characteristic band is due to $\mathrm{O}-\mathrm{H}$ stretching at
$3448.72 \mathrm{~cm}^{-1}, \mathrm{C}-\mathrm{H}$ bending of 1,2,4-substitued aromatic group can be observed at $817.82 \mathrm{~cm}^{-1}$, vinyl group at $995.27 \mathrm{~cm}^{-1}\left(-\mathrm{CH}=\mathrm{CH}_{2}\right.$ bending), and absorption of allyl group (C-Csp ${ }^{2}$ stretching) gives band at $1636.5 \mathrm{~cm}^{-1}$, also present giving signal at about $650-900 \mathrm{~cm}^{-1}$ which are signal benzene aromatic rings. Copolymerization of eugenol and DVB can be characterized by losses of allyl group at $1636.5 \mathrm{~cm}^{-1}$ and vinyl group at $995.27 \mathrm{~cm}^{-1}$. In addition there is absorption at 2931.8 $\mathrm{cm}^{-1}$ which indicates the existence stretching of $\mathrm{CH}-\mathrm{sp}^{3}$.

Fig. $3 a-c$ are spectra of copoly(eugenol-DVB) $2 \%$, $6 \%$ and $12 \%$ The three spectra differ only in their intensity of $\mathrm{CH}-\mathrm{sp}^{3}$ absorption between 2870.08 to $2931.80 \mathrm{~cm}^{-1}$ (Table 3). CH-sp ${ }^{3}$ absorption for copoly(eugenol-DVB) $2 \%$ has a relatively lower area $(103.54)$ than those of copoly(eugenol-DVB) $6 \%$ and $12 \%$ (116.01 and 121.39 respectively). This is because the $\mathrm{CH}-\mathrm{sp}^{3}$ on the last two polymer increase gives the longer area of absorption of the $\mathrm{CH}-\mathrm{sp}^{3}$. Absorption 
Table 3. Comparison of absorption peak areas corresponding to $\mathrm{O}-\mathrm{H}, \mathrm{C}-\mathrm{H}, \mathrm{C}=\mathrm{C}$ and $\mathrm{C}-\mathrm{O}-\mathrm{C}$ bond of copoly(eugenol-DVB)

\begin{tabular}{ccccc}
\hline $\begin{array}{c}\text { copoly } \\
\text { (Eugenol-DVB) }\end{array}$ & -OH & $\begin{array}{c}\mathrm{CH}-\mathrm{sp}^{3} \\
2931.80\end{array}$ & $\begin{array}{c}\mathrm{C}=\mathrm{C} \\
\text { aromatic }\end{array}$ & $\begin{array}{c}\mathrm{C}-\mathrm{O}-\mathrm{C} \\
\text { ether }\end{array}$ \\
& 3448.72 & 2870.08 & 1604.77 & 1033.85 \\
\hline $0 \%$ & 211.52 & 102.25 & 43.37 & 79.55 \\
$2 \%$ & 205.59 & 103.54 & 69.38 & 71.65 \\
$6 \%$ & 244.34 & 116.01 & 74.85 & 101.74 \\
$12 \%$ & 231.40 & 121.39 & 60.05 & 77.06 \\
\hline
\end{tabular}

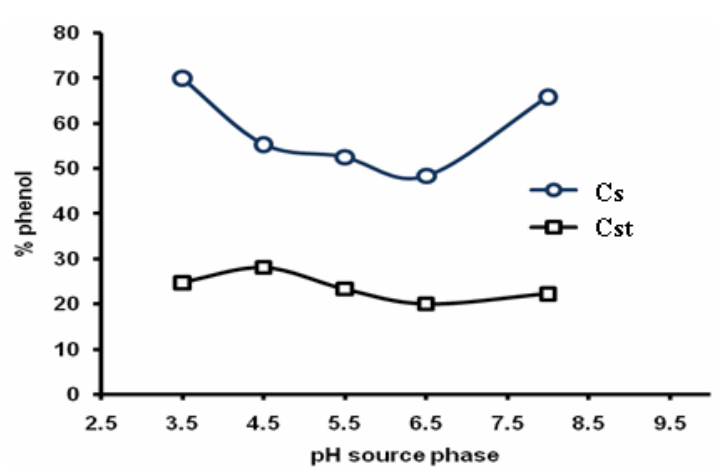

Fig 4. Effect of $\mathrm{pH}$ on phenol transport $\left(\% \mathrm{C}_{\mathrm{s}}\right.$ : concentration of phenol remaining at source phase, $\% \mathrm{C}_{\mathrm{st}}$ : concentration of phenol at stripping phase)

intensity changes of the IR spectra of the copolymer suggest that three copoly(eugenol-DVB) differ in the crosslinking degree corresponding to the amount of DVB added in the copolymer.

\section{Transport of phenol with copoly(eugenol-DVB)}

\section{Effect of $\mathrm{pH}$ of the source phase}

Fig. 4 shows the effect of $\mathrm{pH}$ of source phase on the phenol transport. Percent concentration of phenol remaining in the source phase $\left(\% \mathrm{C}_{\mathrm{s}}\right)$, and the percent concentration of phenol which has transported to stripping phase $\left(\% \mathrm{C}_{\mathrm{st}}\right)$ were measured at different $\mathrm{pH}$ of source phase. The results showed that phenol transport was optimum at the $\mathrm{pH} 4.5$ which achieved a transport efficiency of $24.7 \%$. At this $\mathrm{pH}$, phenol is expected to be in the neutral molecular form, so that allows to make an hydrogen bonding and $\pi-\pi$ interaction with the copoly(eugenol-DVB) in the membrane interface. At higher $\mathrm{pH}$, phenol may be in the anionic phenolate form that more stable in the aqueous phase rather than in the lipophilic membrane phase.

\section{Effect of concentration $\mathrm{NaOH}$}

$\mathrm{NaOH}$ in the stripping phase converts phenol in the membrane phase into sodium phenolate and pull it into the stripping phase. Therefore, high concentration of $\mathrm{NaOH}$ may be preferred for the transport process. The

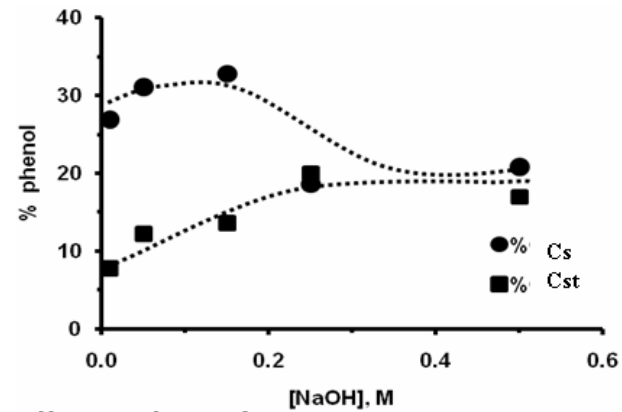

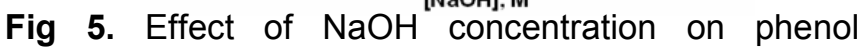
transport

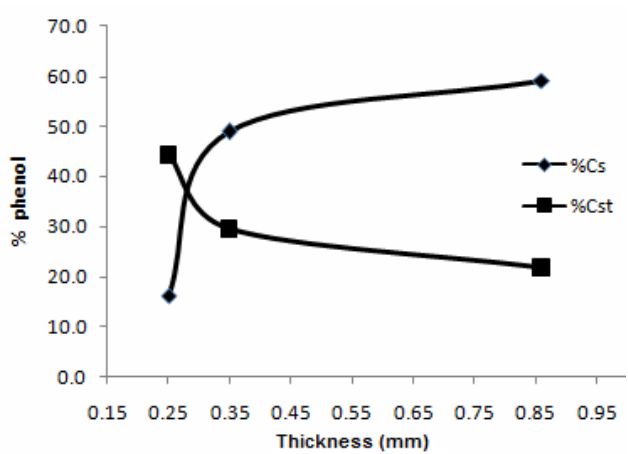

Fig 6. Effect of thickness membrane on phenol transport

difference of electrolyte concentrations between the source phase and the stripping phase is increased by increasing of $\mathrm{NaOH}$ concentration, which causes the difference of osmotic pressure between these two phases' increases. Phenol in the source phase was then transferred to the stripping phase that resulted of increasing of $\% \mathrm{C}_{\mathrm{st}}$.

Fig. 5 shows $\% \mathrm{C}_{\mathrm{s}}$ and $\% \mathrm{C}_{\text {st }}$ at the various $\mathrm{NaOH}$ concentration in the stripping phase, which showed the effect of $\mathrm{NaOH}$ concentration on phenol transport. As seen in the figure, by increasing of $\mathrm{NaOH}$ concentration from $0.01 \mathrm{M}$ to $0.25 \mathrm{M}$, the $\% \mathrm{C}_{\text {st }}$ increased from 7.78 to $20 \%$, and optimum condition was reached at $0.25 \mathrm{M}$. It means that the basicity of stripping phase is critical for improving the kinetics and efficiency of phenol transport. Venkateswaran and Palanivelu [7] observed the phenol transport using vegetable oil as membrane carrier in SLM and showed that optimum $\mathrm{NaOH}$ concentration was $0.2 \mathrm{M}$.

\section{Effect of membrane thickness}

To investigate the influence of membrane thickness on the phenol transport, phenol transport was investigated using membrane with thickness varied to $0.25,0.35$, and $0.86 \mathrm{~mm}$. The results are shown in Fig. 6. Fig. 6 shows that the membrane with thickness $0.86 \mathrm{~mm}$ has $\% \mathrm{C}_{\text {st }}$ of $21.7 \%$, and the thickness $0.25 \mathrm{~mm}$ has $\% \mathrm{C}_{\mathrm{st}}$ of $44.2 \%$. It is due to the membrane 


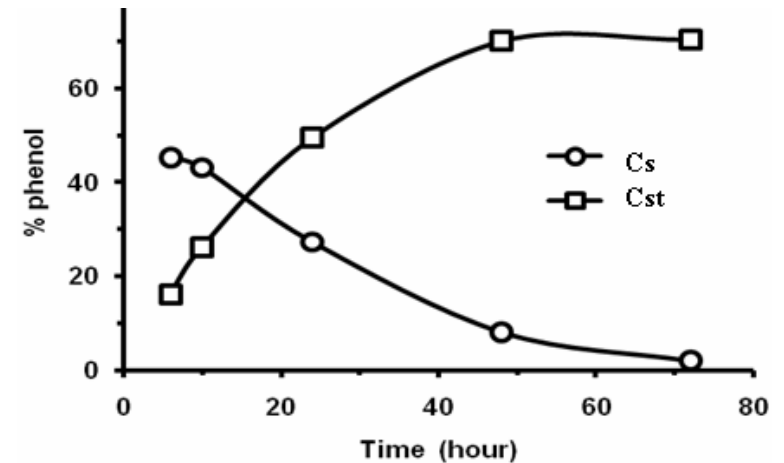

Fig 7. Phenol concentration in the source phase and striping phase at various transport time

with thickness of $0.86 \mathrm{~mm}$ and $0.35 \mathrm{~mm}$ have too much active side, so that the active side cover each other, consequently interaction between the active side of phenol and membrane carriers become ineffective.

On the other hand, the membrane with thickness $0.25 \mathrm{~mm}$ has less plasticizer (DBE) than the membrane with thickness $0.35 \mathrm{~mm}$ and $0.86 \mathrm{~mm}$. Plasticizer in the membrane not only serves to establish or solidify the membrane, but also plays a role in viscosity membrane. The less plasticizer is added in membrane, the viscosity membrane will decrease $[5,10]$. The phenol transport using membrane with thickness $0.35 \mathrm{~mm}$ and $0.86 \mathrm{~mm}$ have less transport than membrane with thickness $0.25 \mathrm{~mm}$. It is possibility due to interaction between phenol and membrane carrier at membrane $0.35 \mathrm{~mm}$ and $0.85 \mathrm{~mm}$ is inhibited by plasticizer.

\section{Effect of transport time}

Transport time is important role on phenol transport because various transport time can provide information about mass transfer, kinetic reaction, membrane permeability and flux. To investigate the effect of transport time on phenol transport, the phenol transport were done at various transport time $(6,10,24,48$, and $72 \mathrm{~h})$.

The results (Fig. 7) shows that the phenol transport increases with increasing of transport time. It is possibility due to the increasing of transport time by increasing of contact time between phenol, membrane, and $\mathrm{NaOH}$ phases, so that interaction between phenol and membrane are longer, these interactions along with the rapid release of ions phenolic to stripping phase.

\section{Effect of crosslinked agent concentration}

A number of DVB in copoly(eugenol-DVB) affected the effectiveness of the result composition of the membrane. The results (Fig. 8) show that the concentration of DVB in the membrane affects the

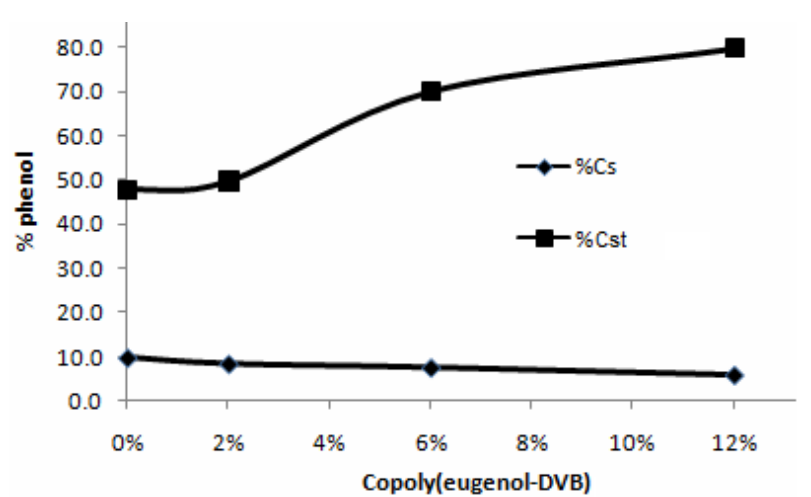

Fig 8. Effect of concentration of copoly(eugenol-DVB) on phenol transport

phenol transport. Fig. 8 shows that increasing of DVB on the membrane will increase $\% \mathrm{C}_{\mathrm{st}}$. Copoly(eugenolDVB) $12 \%$ has the highest $\% \mathrm{C}_{\text {st }}$ i.e. $75.6 \%$. It is due to the greater amount of DVB that used will increase the amount of benzene formed. The higher amount of benzene formed would cause increasing of $\pi-\pi$ interaction between phenol and copoly(eugenol-DVB), so that the phenol transport into strip phase increased.

In the source phase, concentration of phenol decreased with increasing of percentage of the amount DVB. The copoly(eugenol-DVB) $2 \%$ has $\% \mathrm{C}_{\mathrm{s}}$ as $8.3 \%$ and decreased in copoly(eugenol-DVB) $12 \%(5.8 \%)$. Interaction phenol with membrane that has higher percent of DVB was resulted higher phenol transport. It is due to the increasing of DVB will increase $\pi-\pi$ bond between phenol and DVB in the membrane.

\section{SEM of membrane PIM}

The membrane before and after transport characterized by SEM (Fig. 9). Characterization the membrane after transport was performed in all optimum conditions. Fig. 9a,c,e show the copoly(eugenol-DVB) cross-section, the phenol side, and the $\mathrm{NaOH}$ side before transport. This figure show that the membrane carriers copoly(eugenol-DVB) covers almost all the pores of the membrane, thus surface membrane look smooth.

The copoly(eugenol-DVB) cross-section, phenol side and $\mathrm{NaOH}$ side after transport are showed in Fig. $9 b, d, f$. At the cross-section appears the rough part, which shows interaction between phenol and membrane (any phenols have not transport yet to strip phase). On other hand, phenol side shows more smooth than $\mathrm{NaOH}$ side (Fig. 9d,f). It is probably due to as effect of interactions between phenol and membrane carrier, either hydrogen bonding or piinteraction. 


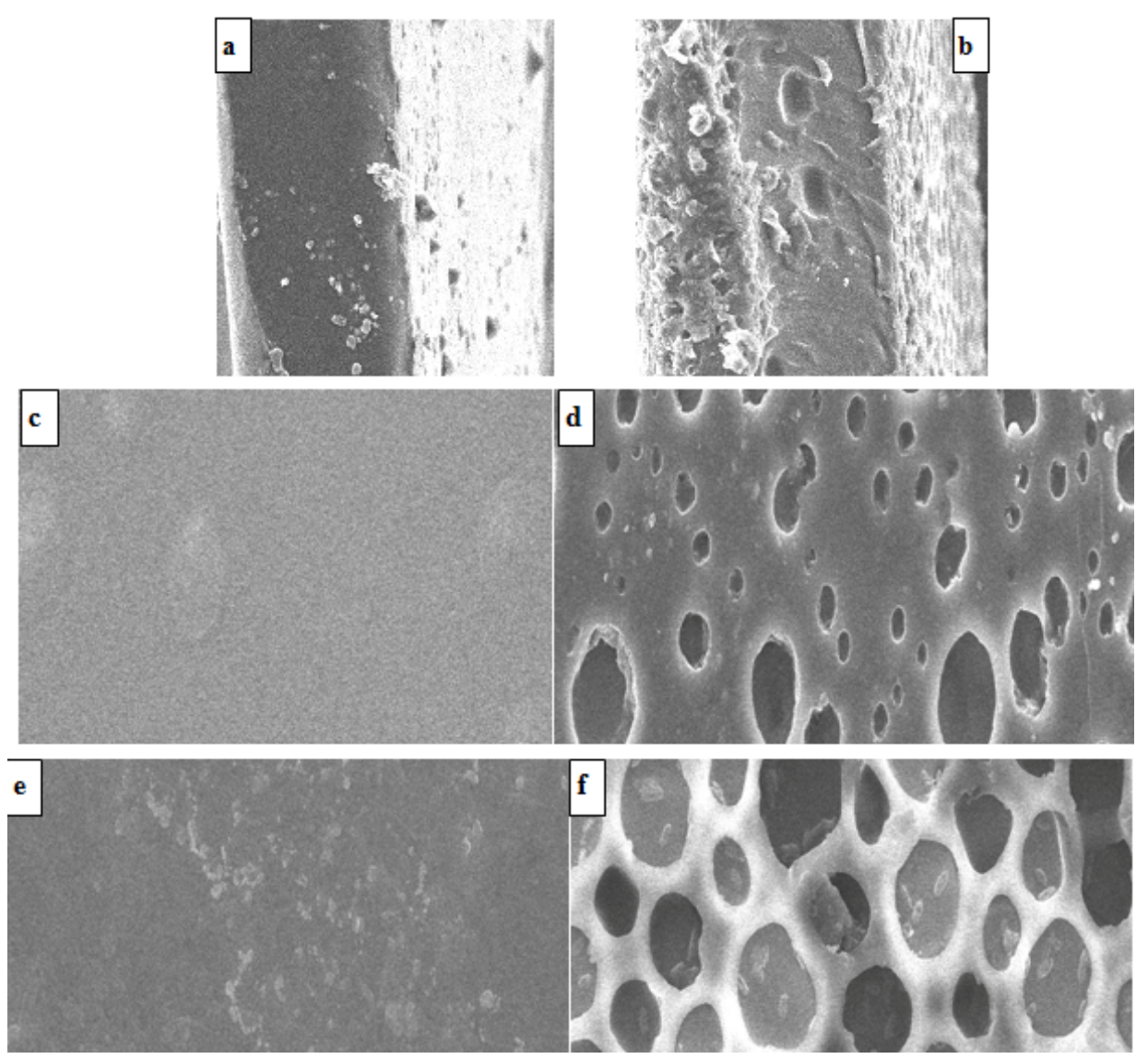

Fig 9. SEM membrane of copoly(eugenol-DVB) 12\%: (a) cross before transport 250x (b) cross after transpor 250x; (c) phenol side before transport 5000x; (d) phenol side after transport 1000x; (e) NaOH side before transport 5000x (f) $\mathrm{NaOH}$ side after transport 1000x

\section{Kinetics, Permeability and flux of transport}

Phenol transport through membrane was occurred by mechanism of transport as effect of phenol concentration gradient in the source phase and strip phase. Reverse phenol transport through the membrane can be prevented by adding a stripping agent $(\mathrm{NaOH})$ into strip phase. Stripping agent convert phenol to be its derivatives i.e. sodium phenolate and traps it in the stripping phase so it does not return to the membrane phase [21].

The process of mass transfer of phenol through the membrane has been determinate. The result shows that $\mathrm{R}^{2}$ obtained (0.986) on phenol transport fit well the kinetic model of first-order.

Based on the assumptions that have been raised by Nghiem [5], the reduction of phenol concentration in the source phase can be described by the equation:

$A J_{s}=-V_{s} \frac{d C_{s}}{d t}$

with initial conditions

$\mathrm{C}_{\mathrm{s}}=\mathrm{C}_{\mathrm{s}}^{0}$ at $\mathrm{t}=0$
While the transport of phenol through the membrane can be described by the following equation:

$\mathrm{J}_{\mathrm{s}}=\mathrm{P}_{\mathrm{s}} \mathrm{C}_{\mathrm{s}}$

so the equation and provide the solution equation:

$\ln \left(\frac{C_{s}}{C_{s}^{0}}\right)=-\left(\frac{A}{V_{s}}\right) P_{s} t$

This equation applies to first-order kinetics, where $A$ is the area of the membrane, $V_{s}$ is the volume of source phase, $t$ is contact time, $C_{s}$ refers to the concentration at time $t$ and $\mathrm{C}^{0}{ }_{s}$ initial concentration of phenol in the source phase, and Ps is the permeability coefficient can be used to characterize the efficiency PIM transport.

A plot of $\ln \left(\mathrm{C}_{s} / \mathrm{C}^{0}{ }_{\mathrm{s}}\right)$ as function of $\mathrm{t}$ is shown in Fig. 10. Phenol concentration in the source phase $\left(\% \mathrm{C}_{\mathrm{s}}\right)$ decreased with increasing of contact time of phenol transport. This result is fitted with the kinetics model of first-order, which shows that the concentration of reactant decreases exponentially with increasing of contact time. First-order kinetics on the phenol transport resulted correlation coefficient $\left(R^{2}\right)$ and mass transfer coefficient (k) of 0.986 and 2.7, respectively. 


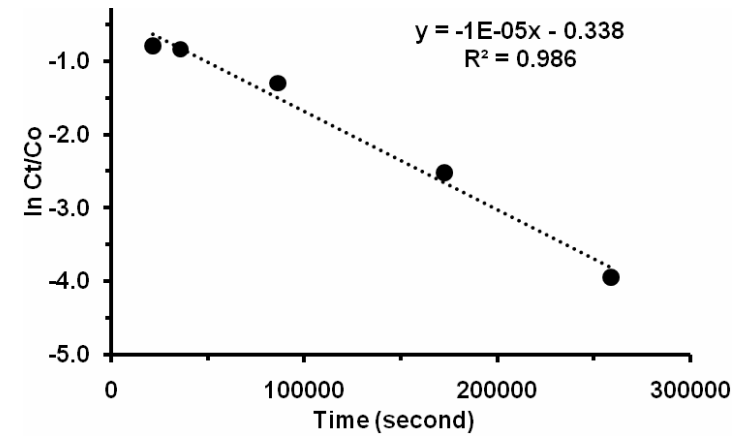

Fig 10. In $\mathrm{C}_{\mathrm{s}} / \mathrm{C}_{\mathrm{s}}{ }^{\circ}$ with time of transport phenol

Permeability can be calculated using the equation (d). In this study, the permeability of PIM in source phase (interface) of $1.5 \times 10^{-4} \mathrm{~m} / \mathrm{s}$, as for flux in the source phase at optimum time $(48 \mathrm{~h})$ of $7.3 \times 10^{-7} \mathrm{~kg} / \mathrm{m}^{2} \mathrm{~s}$.

\section{CONCLUSION}

Preparation of copoly(eugenol-DVB) have been done successfully, as evidenced by FTIR. Results generated for copoly(eugenol-DVB) $2 \%, 6 \%$ and $12 \%$ were $74.16 \%, 71.21 \%$ and $67.42 \%$, respectively. The copoly(eugenol-DVB) can be used as a membrane carrier for phenol transport using PIM method. The ability of phenols transport was optimum on copoly(eugenol-DVB) $12 \%$, which is equivalent to $75.6 \%$ at condition of $\mathrm{pH}$ phenol of $4.5, \mathrm{NaOH}$ concentration of $0.25 \mathrm{M}$, thickness of $0.25 \mathrm{~mm}$ and transport time of $48 \mathrm{~h}$.

\section{ACKNOWLEDGEMENT}

Many thanks to all who helped in this study, especially Nurtina Muktiarti.

\section{REFERENCES}

1. Gonzalez-Muñoz, M.J., Luque, S., Alvarez, J.R., and Coca, J., 2003, J. Membr. Sci., 213, 1-2, 181-193.

2. De Gyves, J., and de san Miguel, E.R., 1999, Ind. Eng. Chem. Res., 38, 6, 2182-2202.

3. Stanisavljvici, M., and Nidic, L., 2004, Working Living Environ. Prot., 2, 4, 345-349.
4. Yang, X.J., Fane A.G., and Fell, C.J.D, 2003, Ind. Eng. Chem. Res., 42, 2, 392-403.

5. Nghiem, L.D., Mornane, P., Potter, I.D., Perera, J.M., Cattrall, R.W., and Kolev, S.D., 2006, J. Membr. Sci., 281, 7-41.

6. Kocherginsky, N.M., Yang, Q., and Seelam, L., 2007, Sep. Purif. Technol., 53, 171-177.

7. Venkateswaran P., and Palanivelu K., 2006, J. Hazard. Mater., 131, 146-152.

8. Huidong, Z., Biyu, W., Yanxiang, W.U., and Qilong, R.E.N., 2009, Chin. J. Chem. Eng., 17, 5, 750-755.

9. Hill, C., Dojol, J.F., Rouquette, H., Eymard, S., and Tournois, B., 1996, J. Membr. Sci., 114, 1, 73-80.

10. Gardner, J.S., Peterson, Q.P., Walker, J.O., Jensen, B.D., Adhikary, B., Harrison, R.G., and Lamb, J.D., 2006, J. Membr. Sci., 277, 165-167.

11. Fontas, C., Tayeb, R., Dhahbi, M., Gaudichet, E., Thominette, F., Roy, P., Steenkeste, K., FontaineAupart, M., Tingry, S., Tronel-Peyroz, E., and Seta, P., 2007, J. Membr. Sci., 290, 1-2, 62-72.

12. Lamb, J.D., West, J.N., Shaha, D.P., and Johnson, J.C., 2010, J. Membr. Sci., 365, 256-259.

13. Kim, J.S., Lee, S.H., Yu, S.H., Cho, M.H., Kim, D.W., Kwon S.G., and Lee, E.H., 2002, Bull. Korean Chem. Soc., 23, 8, 1085-1088.

14. Tayeb, R., Fontas, C., Dhahbi, M., Tingry, S., and Seta, P., 2005, Sep. Purif. Technol., 42, 2, 189193.

15. Levitskaia, T.G., Lamb, J.D., Fox, K.L., and Moyer, B.A., 2002, Radiochim. Acta, 90, 1, 43-52.

16. Kim, J.S., Kim, S.K., Cho, M.H., Lee, S.H., Kim, J.Y., Kwon, S.G., and Lee, E.H., 2001, Bull. Korean Chem. Soc., 22, 10, 1076-1080.

17. Scindia, Y.M., Pandey, A.K., and Reddy, A.V.R., 2005, J. Membr. Sci., 249, 1-2, 143-152.

18. Li, J.M., Meng, X.G., Hu, C.W., and Du, J., 2009, Bioresour. Technol., 100, 3, 1168-1173.

19. Sousa, A.R., and Trancoso, M.A., 2009, Talanta, 79, 3, 796-803.

20. Correia, P.F.M.M., and de Carvalho, J.M.R., 2003, J. Hazard. Mater., 225, 1-2, 41-49.

21. Mortaheb, H.R., Amini, M.H., Sadeghian, F., Mokhtarani, B., and Daneshyar, H., 2008, J. Hazard. Mater., 160, 2-3, 582-588. 